\title{
The Effect of Aminophylline on Diaphragm Blood Flow in the Piglet
}

\author{
DENNIS E. MAYOCK, GARY A. TWIGGS, THOMAS A. STANDAERT, JON F. WATCHKO, AND \\ DAVID E. WOODRUM \\ Department of Pediatrics, Division of Neonatal and Respiratory Diseases, University of Washington, \\ Seattle, Washington 98195
}

\begin{abstract}
The effect of aminophylline on diaphragmatic blood flow was investigated in two groups of newborn piglets. Six animals were studied during spontaneous breathing and seven additional animals were paralyzed and ventilated to assess the effect of aminophylline on blood flow to the nonworking diaphragm. Arterial blood gases and $\mathrm{pH}$, cardiac output, and diaphragmatic blood flow were measured before and $20 \mathrm{~min}$ after infusion of $20 \mathrm{mg} / \mathrm{kg}$ aminophylline. Blood theophylline concentrations averaged $117 \mu \mathrm{mol} / \mathrm{L}(21 \mu \mathrm{g} / \mathrm{mL})$ in both groups of animals. Heart rate increased significantly in all animals. Cardiac output increased significantly only in spontaneously breathing animals. Aminophylline had no effect on blood flow to the costal or crural portions of the diaphragm in either the paralyzed or spontaneously breathing animals. (Pediatr Res 26:196-199, 1989)
\end{abstract}

Abbreviation

Qddi, diaphragmatic blood flow

Methylxanthines, and in particular the theophylline preparations, have been proposed as adjunctive therapy in weaning premature infants from mechanical ventilation $(1,2)$. In addition to their bronchodilatory effect (3-5) and central respiratory stimulation (6-9), methylxanthines improve diaphragmatic force output (10-13) and ameliorate the effects of diaphragmatic fatigue $(10,14-16)$ in adult humans and experimental animals. Similar information is not available for the newborn animal or infant.

Previous studies have suggested that aminophylline improves diaphragmatic function via a direct effect on muscle fiber contractility (17-19). It may also improve diaphragmatic contractility and protect from fatigue by increasing muscle blood flow $(20$, 21 ) and, thereby, substrate delivery (22). This study was designed to determine whether aminophylline has a primary effect on blood flow to the diaphragm in the piglet.

\section{MATERIALS AND METHODS}

A total of 13 farm-bred Yorkshire piglets were studied between 10 and $40 \mathrm{~d}$ of age; they weighed 2.7 to $5.2 \mathrm{~kg}$. Only healthy animals with a respiratory rate of $15-30$ breaths $/ \mathrm{min}, \mathrm{a} \mathrm{PaO}_{2}$ of

Received February 17, 1989; accepted May 5, 1989.

Correspondence Dennis E. Mayock, M.D., Division of Neonatal and Respiratory Diseases, Department of Pediatrics RD-20, University of Washington, Seattle, WA 98195.

Supported in part by Pediatric Pulmonary Training Grant MCJ 000955 and HL 39187 and a Fellowship from the American Lung Association of Washington (G.A.T.). more than $8.0 \mathrm{kPa}$ (60 torr) in room air, and a $\mathrm{PaCO}_{2}$ equal to or less than $6.7 \mathrm{kPa}$ (50 torr) were accepted for study. The animals were anesthetized with sodium pentobarbital $(15 \mathrm{mg} / \mathrm{kg}$ intravenously) and studied in the supine position. Subsequent doses of anesthesia were given as needed to prevent jaw clonus.

The trachea was surgically exposed and a metal tracheostomy tube was inserted. A femoral artery and vein were cannulated to monitor blood pressure, assess arterial blood gases and $\mathrm{pH}$, and administer drugs. Arterial $\mathrm{pH}$ and blood gas tensions were measured with a Corning 168 blood gas analyzer (Corning Glass Works, Medfield, MA). Rectal temperature was continuously monitored (Telethermometer 43TA, Yellow Springs Instrument, Yellow Springs, $\mathrm{OH}$ ) and maintained between 38.5 and $39.5^{\circ} \mathrm{C}$. (23) with a radiant warmer. A 5 French thermodilution catheter was placed into the left branch of the pulmonary artery via the right external jugular vein under fluoroscopy. Cardiac output determinations were made in triplicate using a 9520A Cardiac Output computer (American Edwards Laboratories, Irvine, CA). Radiolabeled microspheres were used to measure diaphragmatic blood flow utilizing the reference sample method described by Heymann et al. (24). A polyethylene catheter (PE 90) was advanced into the left ventricle via the left carotid artery under fluoroscopic guidance for microsphere injection. Location of catheter tip was confirmed by pressure tracing and at postmortem. A second polyethylene catheter was placed into a femoral artery for withdrawal of the reference sample using a calibrated withdrawal pump (Harvard Apparatus, Millis, MA). The $15-\mu$ microspheres labeled with either ${ }^{46} \mathrm{Sc},{ }^{95} \mathrm{Nb},{ }^{103} \mathrm{Ru}$, or ${ }^{141} \mathrm{Ce}$ (DuPont, Wilmington, DE) were used in these experiments. Approximately 1 million microspheres were diluted to a total volume of $2 \mathrm{~mL}$ with heparinized $0.9 \%$ saline. Before injection, the microsphere solutions were sonicated for $2 \mathrm{~min}$, then shaken with a vortex mixer for $2 \mathrm{~min}$. The microspheres were injected via the left ventricular catheter over a 30 -s period whereas a simultaneous arterial reference sample was withdrawn from the aorta at a rate of $4.12 \mathrm{~mL} / \mathrm{min}$ for $2 \mathrm{~min}$, beginning $10 \mathrm{~s}$ before initiation of the injection. At the end of the experiment, the animal was killed with an overdose of sodium pentobarbital. The diaphragm, both kidneys and the lungs were removed and all fat was excised. The central tendon was removed from the diaphragm and the costal and crural components were separated and weighed. Tissue specimens were counted with a gamma scintillation spectrometer (Minaxi 5000 series, Packard, Laguna Hills, CA). Comparative blood flow to right and left kidneys was used as an index of adequate microsphere mixing within the left ventricle. Only those injections that resulted in a less than $15 \%$ difference between the two kidneys were used in analysis (24). Diaphragmatic vascular conductance was calculated by dividing the tissue blood flow values by the mean blood pressure measurement and was then expressed as $\mathrm{mL} \cdot(\mathrm{g} \cdot \mathrm{min} \cdot \mathrm{mm} \mathrm{Hg})^{-1} \times$ $10^{3}$.

Aminophylline was diluted in $5 \%$ dextrose in water before 
being administered intravenously in a dose of $20 \mathrm{mg} / \mathrm{kg}$ over a 10 -min period. Postaminophylline studies were performed 20 min after the completion of the infusion and a blood sample for theophylline concentration was obtained at that time.

Two groups of animals were studied: in one group $(n=6)$, animals were allowed to breath $50 \% \quad \mathrm{O}_{2}$ spontaneously. A hot wire anemometer was used to measure tidal flow and the flow signal was integrated (Hewlett Packard 8815 A, Palo Alto, CA) to determine tidal volume. In a second group $(n=7)$, animals were paralyzed with pancuronium bromide $(0.3 \mathrm{mg} / \mathrm{kg})$ and mechanically ventilated with an $\mathrm{FiO}_{2}$ of 0.5 and a fixed volume ventilator with a tidal volume of $12-15 \mathrm{~mL} / \mathrm{kg}$. Frequency was adjusted to maintain $\mathrm{PaCO}_{2}$ between $4.0-6.7 \mathrm{kPa}$ (30-50 torr) (Harvard Apparatus, Millis, MA). Additional doses of pancuronium were given as needed to prevent spontaneous breathing. This group served as a control for variations in Qdi that might occur with fluctuations in spontaneous ventilation.

Results are presented as mean \pm SD unless otherwise noted. Differences in measured variables within a group were determined by the Student's $t$ test (Minitab Release 80.1, Pennsylvania State University, University Park, PA, 1980).

Experimental protocol. The protocol was identical for both animal study groups. After a 30 -min stabilization period, baseline hemodynamic (heart rate, blood pressure, cardiac output) and ventilatory (respiratory frequency, tidal volume) measurements were made and microspheres were injected. A total of $20 \mathrm{mg} / \mathrm{kg}$ of aminophylline was administered and the above measurements were repeated at 20 min postinfusion. Blood was drawn for a theophylline concentration, the animal was killed, and tissues were prepared for microsphere analysis.

\section{RESULTS}

Serum theophylline concentrations averaged $112 \pm 4.4 \mu \mathrm{mol} /$ $\mathrm{L}(20.2 \pm 0.8 \mu \mathrm{g} / \mathrm{mL})$ in paralyzed and $119 \pm 2.8 \mu \mathrm{mol} / \mathrm{L}(21.5$ $\pm 0.5 \mu \mathrm{g} / \mathrm{mL}$ ) in spontaneously breathing animals. At these levels, aminophylline had no effect on arterial blood gas values in either group (Table 1).

Heart rate increased in both groups after aminophylline administration whereas mean BP was unchanged (Table 2). An increase in cardiac output after aminophylline reached statistical significance in spontaneously breathing animals but not in paralyzed animals. Aminophylline increased minute ventilation $40 \%(p=0.041)$ in the spontaneously breathing animals.
Aminophylline had no effect on costal or crural diaphragmatic blood flow (Fig. 1). Vascular conductance of the total diaphragm, although higher in the spontaneously breathing versus paralyzed animals at baseline $\left(3.4 \pm 0.5 \times 10^{3} \mathrm{~mL} \cdot(\mathrm{g} \cdot \mathrm{min} \cdot \mathrm{mm} \mathrm{Hg})^{-1}\right.$ versus $\left.1.3 \pm 0.2 \times 10^{3} \mathrm{~mL} \cdot(\mathrm{g} \cdot \mathrm{min} \cdot \mathrm{mm} \mathrm{Hg})^{-1}\right)$, was not altered by aminophylline administration.

\section{DISCUSSION}

Aminophylline has no effect on diaphragmatic blood flow or vascular conductance in the nonfatigued piglet diaphragm whether working (spontaneously breathing) or resting (paralyzed). Aminophylline increased minute ventilation in the spontaneously breathing animals as expected (7). Both groups of animals manifested the expected cardiovascular effects of the drug (25).

Skeletal muscle fatigue, and presumably diaphragmatic fatigue, occurs when the metabolic demands of the muscle exceed the nutrient supply $(20,26,27)$, with blood flow being one major determinant of that supply. Thus, the ability to increase diaphragmatic blood flow might be expected to prevent the development of or treat already established diaphragmatic fatigue (22). Several nonspecific vasoactive drugs do improve diaphragmatic blood flow. Bundy et al. (28) found that amrinone may improve endurance as a direct effect of its diaphragmatic blood flow augmentation. Similarly, Scharf et al. (29) found that isoproterenol resulted in an increase in diaphragmatic blood flow at a given level of diaphragmatic activity when blood pressure was controlled.

Methylxanthines may also have direct vasodilating properties and, in part, improve muscle contractility by augmenting blood flow $(30,31)$. Oglivie et al. (30) demonstrated that in human adult volunteers, aminophylline at a blood concentration of 28 $111 \mu \mathrm{mol} / \mathrm{L}(5-20 \mu \mathrm{g} / \mathrm{mL})$ resulted in a dose-dependent increase in forearm blood flow and a decrease in forearm vascular resistance in subjects at rest. In adult dogs, Komarek et al. (31) found that theophylline resulted in a significant decrease in total peripheral vascular resistance, accompanied by a $10 \%$ increase in cardiac output. Similarly, Kariya et al. (32) found that aminophylline resulted in a decrease in perfusion pressure without changing Qdi and concluded that aminophylline decreases diaphragmatic vascular resistance.

The values obtained in this study for diaphragmatic blood flow in the quietly breathing neonatal piglet are similar to pre-

Table 1. Arterial blood gas and $p H$ determinations (mean $\pm S D$ )

\begin{tabular}{|c|c|c|c|c|c|}
\hline & \multirow[b]{2}{*}{$\mathrm{pH}$} & \multicolumn{2}{|c|}{$\mathrm{PaCO}_{2}$} & \multicolumn{2}{|c|}{$\mathrm{PaO}_{2}$} \\
\hline & & $\mathrm{kPa}$ & (torr) & $\mathrm{kPa}$ & (torr) \\
\hline \multicolumn{6}{|l|}{ Paralyzed $(n=7)$} \\
\hline Before aminophylline & $7.40 \pm 0.09$ & $4.5 \pm 0.9$ & $(34 \pm 7)$ & $30.3 \pm 3.9$ & $(227 \pm 29)$ \\
\hline After aminophylline & $7.41 \pm 0.08$ & $4.9 \pm 1.6$ & $(37 \pm 12)$ & $30.4 \pm 3.7$ & $(228 \pm 28)$ \\
\hline \multicolumn{6}{|c|}{ Spontaneously breathing $(n=6)$} \\
\hline Before aminophylline & $7.38 \pm 0.04$ & $5.7 \pm 0.9$ & $(43 \pm 7)$ & $22.8 \pm 6.1$ & $(171 \pm 46)$ \\
\hline After aminophylline & $7.39 \pm 0.04$ & $5.5 \pm 0.5$ & $(41 \pm 4)$ & $24.7 \pm 6.0$ & $(185 \pm 45)$ \\
\hline
\end{tabular}

Table 2. Hemodynamic and ventilatory measurements (mean \pm SEM)

\begin{tabular}{|c|c|c|c|c|c|}
\hline & $\begin{array}{l}\text { Heart rate } \\
(\mathrm{bpm})\end{array}$ & $\begin{array}{l}\text { Mean BP } \\
(\mathrm{mm} \mathrm{Hg})\end{array}$ & $\begin{array}{l}\text { Cardiac output } \\
(\mathrm{mL} / \mathrm{kg} / \mathrm{min})\end{array}$ & $\begin{array}{c}\text { Frequency } \\
\text { (breaths/ } \\
\text { min) }\end{array}$ & $\begin{array}{c}\text { Minute } \\
\text { ventilation } \\
(\mathrm{mL} / \mathrm{kg} / \mathrm{min})\end{array}$ \\
\hline \multicolumn{6}{|l|}{ Paralyzed animals $(n=7)$} \\
\hline Before aminophylline & $192 \pm 15$ & $99 \pm 5$ & $196 \pm 18$ & $28 \pm 1$ & $317.7 \pm 38.6$ \\
\hline After aminophylline & $243 \pm 12^{*}$ & $91 \pm 5$ & $214 \pm 27$ & $28 \pm 1$ & $321.3 \pm 45.9$ \\
\hline \multicolumn{6}{|c|}{ Spontaneously breathing animals $(n=6)$} \\
\hline Before aminophylline & $186 \pm 9$ & $88 \pm 11$ & $263 \pm 19$ & $30 \pm 4$ & $284.4 \pm 45.2$ \\
\hline After aminophylline & $256 \pm 14^{*}$ & $87 \pm 9$ & $296 \pm 18 *$ & $34 \pm 5$ & $398.4 \pm 54.4^{*}$ \\
\hline
\end{tabular}

\footnotetext{
${ }^{*} p<0.05$ compared to baseline value.
} 


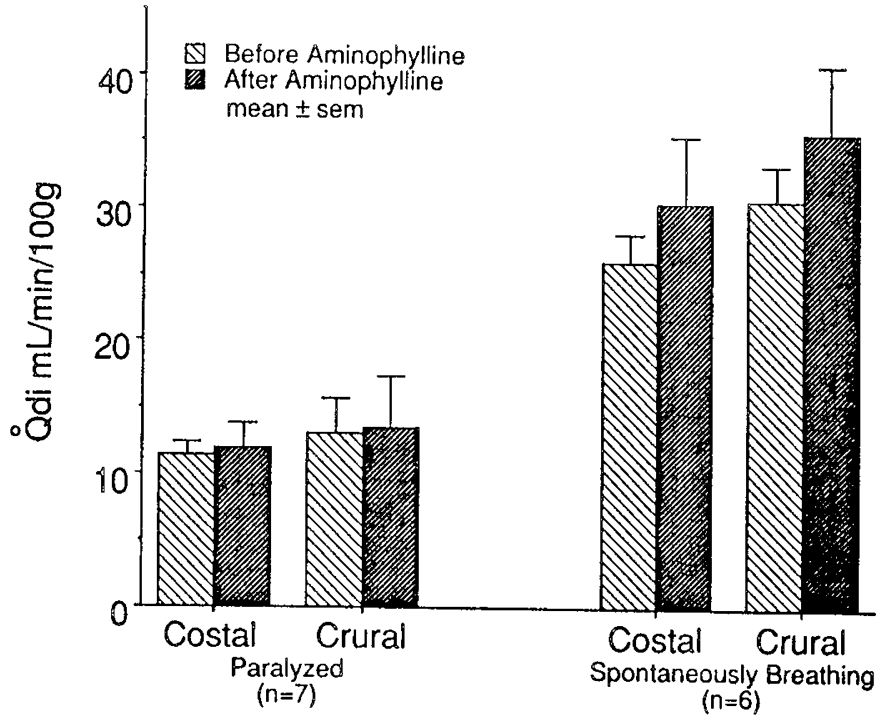

Fig. 1. Effect of aminophylline on diaphragmatic blood flow in paralyzed ventilated and in spontaneously breathing animals. No differences in blood flow was noted between the costal and crural segments of the diaphragm in either group of animals. No significant differences were noted after aminophylline administration.

viously published estimates of Qdi that were based on a variety of techniques applied to a number of different species $(28,33-$ $36)$. In contrast to the studies involving adult study subjects, our data point to the conclusion that aminophylline has no vasodilatory effect in the piglet diaphragm. Additionally, we were able to confirm a significantly higher baseline Qdi in the animals who were spontaneously breathing. The latter data support the concept that one primary regulator of diaphragmatic blood flow is the metabolic demand of the muscle, the chief element of which is the level of contractile activity.

Several possibilities exist to explain the contrasting results of this study in the piglet as compared to those in adult experimental animals $(31,32)$. First, the piglet diaphragm, like that of other newborn mammalian species $(37,39,40)$ is structurally and enzymatically different than its adult counterpart (37-40). The developing diaphragm has a much higher proportion of type IIA and a much lower proportion of type I and type IIB fibers; there are a significant number of type IIC fibers, which are completely absent in the adult diaphragm (37). In addition, the crosssectional area of all fiber types is smaller in the neonatal as opposed to the adult diaphragm (37-40). This may have functional implications relating to control of diaphragmatic blood flow; it has been speculated that larger fibers may be more sensitive to limitations of substrate delivery due to greater diffusion distances (38).

The lack of increase in blood flow associated with the increase in ventilation induced by aminophylline in the spontaneously breathing animals is mostly likely a reflection of the relatively minor metabolic demand presented by the $40 \%$ increase in ventilation. Indeed, our findings confirm those of Rochester and Bettini (35) who found that during quiet breathing, diaphragmatic blood flow had no significant relationship to minute ventilation in adult dogs. This study demonstrates that in the young piglet, aminophylline does not have any direct vasoactive influence resulting in changes in blood flow in either paralyzed or spontaneously breathing animals.

\section{REFERENCES}

1. Harris MC, Baumgart S, Rooklin AR, Fox WW 1983 Successful extubation of infants with respiratory distress syndrome using aminophylline. $J$ Pediatr 103:303-305

2. Viscardi RM, Faix RG, Nicks JJ, Grasela TH 1985 Efficacy of theophylline for prevention of post-extubation respiratory failure in very low birth weight infants. J Pediatr 107:469-472

3. Mitenko PA, Ogilvie RI 1973 Rational intravenous doses of theophylline. $N$ Engl J Med 289:600-603

4. Nassif EG, Weinberger M, Thompson R, Huntley W 1981 The value of maintenance theophylline in steroid-dependent asthma. $N$ Engl $J$ Med 304:71-75

5. Weinberger MM, Bronsky EA 1974 Evaluation of oral bronchodilator therapy in asthmatic children. J Pediatr 84:421-427

6. Dowell AR, Heyman A, Sieker HO, Tripathy K 1965 Effect of aminophylline on respiratory-center sensitivity in cheyne-stokes respiration and in pulmonary emphysema. N Engl J Med 273:1447-1453

7. Eldridge FL, Millhorn DE, Waldrop TG, Kiley JP 1983 Mechanism of respiratory effects of methylxanthines. Respir Physiol 53:239-261

8. Galdston M, Geller J 1957 Effects of aminophylline and diamox alone and together on respiration and acid-base balance and on respiratory response to carbon dioxide in pulmonary emphysema. Am J Med 23:183-196

9. Gerhardt T, McCarthy J, Bancalari E 1979 Effect of aminophylline on respiratory center activity and metabolic rate in premature infants with idiopathic apnea. Pediatrics 63:537-542

10. Aubier M, De Troyer A, Sampson M, Macklem PT, Roussos C 1981 Aminophylline improves diaphragmatic contractility. N Engl J Med 305:249-252

11. Dimarco AF, Nochomovitz M, Dimarco MS, Altose MD, Kelson SG 1985 Comparative effects of aminophylline on diaphragm and cardiac contractility. Am Rev Respir Dis 132:800-805

12. Howell S, Fitzgerald RS, Roussos Ch 1985 Effects of aminophylline, isoproterenol, and neostigmine on hypercapnic depression of diaphragmatic contractility. Am Rev Respir Dis 132:241-247

13. Sigrist S, Thomas D, Howell S, Roussos Ch 1982 The effect of aminophylline on inspiratory muscle contractility. Am Rev Respir Dis 126:46-50

14. Howell S, Roussos C 1984 Isoproterenol and aminophylline improve contractility of fatigued canine diaphragm. Am Rev Respir Dis 129:1 18-124

15. Murciano D, Aubier M, Lecocguic Y, Pariente R 1984 Effects of theophylline on diaphragmatic strength and fatigue in patients with chronic obstructive pulmonary disease. N Engl J Med 311:349-353

16. Viires N, Aubier M, Murciano D, Fleury B, Talamo C, Pariente R 1984 Effects of aminophylline on diaphragmatic fatigue during acute respiratory failure. Am Rev Respir Dis 129:396-402

17. Aubier M, Murciano D, Viires N, Lecocguic Y, Patiente R 1983 Diaphragmatic contractility enhanced by aminophylline: role of extracellular calcium. J Appl Physiol 54:460-464

18. Esau SA 1988 Theophylline prevents the depolarization of skeletal muscle membrane by hypoxic, hypercapnic acidosis. Am Rev Respir Dis 137:385(abstr)

19. Viires N, Aubier M, Murciano D, Marty C, Pariente R 1986 Effects of theophylline on isolated diaphragmatic fibers. Am Rev Respir Dis 133:10601064

20. Macklem PT, Roussos C 1977 Respiratory muscle fatigue: a cause of respiratory failure? Clin Sci Mol Med 53:419-422

21. Jones DA, Howell S, Roussos C, Edwards RHT 1982 Low frequency fatigue in isolated skeletal muscles and the effects of methylxanthines. Clin Sci 63:161-167

22. Supinski G, Dimarco A, Ketai L, Hussein F, Altose M 1988 Reversibility of diaphragm fatigue by mechanical hyperperfusion. Am Rev Respir Dis 138:604-609

23. Mount LE, Ingram DL 1971 Physiology. In: The Pig as a Laboratory Animal. Academic Press, New York, pp 65-78

24. Heymann MA, Payne BD, Hoffman JIE, Rudolph AM 1977 Blood flow measurements with radionuclide-labeled particles. Prog Cardiovasc Dis 20:55-79

25. Fixler DE, Atkins JM, Mitchell JH, Horwitz LD 1976 Blood flow to respiratory, cardiac, and limb muscles in dogs during graded exercise. Am J Physiol 231:1515-1519

26. Roussos C, Macklem PT 1977 Diaphragmatic fatigue in man. J Appl Physiol 43:189-197

27. Roussos C 1985 Function and fatigue of respiratory muscles. Chest $88: 124 \mathrm{~S}$ $132 \mathrm{~S}$

28. Bundy RJ, Arnold JS, Hussein F, Supinski G 1986 Effect of amrinone on diaphragm blood flow. Am Rev Resp Dis 133:A253(abstr)

29. Scharf SM, Bark H, Einhorn S, Tarasiuk A 1986 Blood flow to the canine diaphragm during hemorrhagic shock. Am Rev Resp Dis 133:205-211

30. Ogilvie RI, Fernandez PG, Winsberg F 1977 Cardiovascular response to increasing theophylline concentrations. Eur J Clin Pharmacol 12:409-414

31. Komarek VJ, Cartheuser C, Mansfeld C, Fleck C 1977 Der effekt von pentoxifyllin, xantinol-nicotinat und theophyllin auf das kreislaufsystem, die myokardiale dynamik und die linksventrikulare kontraktilitat beim hund im akuten experiment. Arzneimittelforschung 27:1932-1939

32. Kariya S, Scharf S, Brown R 1985 Effects of aminophylline on diaphragm perfusion and oxygen consumption. Am Rev Respir Dis 131:A338(abstr)

33. Kendrick JE, DeHaan SJ, Parke JD 1981 Regulation of blood flow to respiratory muscles during hypoxia and hypercapnia. Proc Soc Exp Biol Med 166:157-161

34. Robertson CH, Pagel MA, Johnson RL 1977 The distribution of blood flow, oxygen consumption and work output among the respiratory muscles during unobstructed hyperventilation. J Clin Invest 59:43-50

35. Rochester DF, Bettini G 1976 Diaphragmatic blood flow and energy expendi- 
ture in the dog. J Clin Invest 57:661-672

36. Rosenberg AA, Koehler RC, Jones MD 1984 Distribution of cardiac output in fetal and neonatal lambs with acute respiratory acidosis. Pediatr Res 18:731-735

37. Mayock DE, Hall J, Watchko JF, Standaert TA, Woodrum DE 1987 Diaphragmatic muscle fiber type development in swine. Pediatr Res 22:449-454

38. Sieck GC, Sacks RD, Blanco CE, Edgerton VR 1986 SDH activity and cross- sectional area of muscle fibers in cat diaphragm. J Appl Physiol 60:12841292

39. Davies AS, Gunn HM 1972 Histochemical fibre types in the mammalian diaphragm. J Anat 112:41-60

40. Maxwell LC, McCarter RJM, Kuehl TJ, Robotham JL 1983 Development of histochemical and functional properties of baboon respiratory muscles. $J$ Appl Physiol 54:551-561

\section{Announcements}

\section{Joint PhD-Fellowship Training Program}

The University of Chicago Department of Pediatrics announces its unique, new Pediatric Science Training/ $\mathrm{PhD}$ Program. Trainees wishing to pursue an academic career may simultaneously pursue subspecialty training and a graduate school program leading to the $\mathrm{PhD}$ degree in this 5-year program. Training is available in most pediatric subspecialties, and research opportunities are available in diverse fields, including the social and behavioral sciences as well as the biological sciences. Applications are being accepted for 1990 and 1991. This program is funded by the National Institutes of Child Health and Human Development. Address inquiries to Robert L. Rosenfield, MD, Program Director. Pediatric Science Training/PhD Program, Wyler Children's Hospital, 5841 South Maryland, Chicago, IL 60637

\section{Sixth Cooley's Anemia Symposium}

The New York Academy of Sciences is sponsoring the Sixth Cooley's Anemia Symposium, March 13-15, 1990, at the Sheraton Centre in New York City. The overall goal of the symposium is to exchange views on recent advances in the biology, diagnosis, and treatment of thalassemia (Cooley's anemia). Investigators from around the world will discuss recent advances in: 1) precise identification of the molecular defects in the thalassemias; 2) new techniques for prenatal diagnosis; 3) current therapy for thalassemia; and 4) newer methods of therapy, including oral iron chelators, bone marrow transplantation, and gene therapy. For further information contact the Conference Department, New York Academy of Sciences, 2 East 63rd Street, New York, Ny 10021 (212) 838-0230.

\section{ND INTERNATIONAL CONGRESS OF TROPICAL PEDIATRICS}

The 2nd International Congress of the International Society of Tropical Pediatrics will be held March 12-16, 1990 in Nairobi, Kenya. For information contact Prof. Nimrod O. Bwibo or Dr. G.M. Anabwani of the Organizing Committee, UNAPSA/ISTP Congress, P.O. Box 19676, Nairobi, Kenya. 